\title{
Free, Prior and Informed Consent (FPIC) as a Conflict Mitigation Instrument : FPIC Applicability for Mitigation of Structural Agrarian Conflicts in Indonesia
}

\author{
Elfitra $^{1}$, Afrizal $^{2}$, Zuldesni $^{3}$ \\ \{ elbaiko69@gmail.com ${ }^{1}$, afrizal_2002au@yahoo.com², \\ desni_piliang@yahoo.com $\left.{ }^{3}\right\}$ \\ Sociology Department, Andalas University, Padang, Indonesia
}

\begin{abstract}
In Indonesia the resistance of indigenous communities, which escalates to the use of violence acts, to plantation companies, mining and the government regarding land acquisition continues until post-reform. The main issue is land grabbing or land acquisition that does not show recognition and respect for land rights based on customs. Free, Prior and Informed Consent (FPIC) principles and criteria are recommended by activists and international agencies for the mitigation of agrarian conflict. The questions to be answered in this article are: a) why FPIC is used as an instrument for mitigating structural agrarian conflicts, b) where FPIC's ideas come from, c) what are the fundamentals of FPIC, d) is FPIC applicable in the legal context of Indonesia. To answer these four questions, we analyzed library sources and legislation on environmental permits, plantations and forest governance. FPIC is an international standard that is recommended to be applied to overcome the weaknesses of national law in respecting land rights based on customs. The essence of FPIC is the recognition of the rights of affected indigenous communities to self-determination. Based on the review of legislation on environmental permits, land acquisition for public purposes and determination of conservation area, this article will show that FPIC is feasible to apply in Indonesia. This article contributes to the development of knowledge on the mitigation of agrarian conflicts with respect to land rights based on custom, especially on land grabbing literature and how to recognize indigenous peoples' rights to land in plantation investments and forest conservation.
\end{abstract}

Keywords: Agrarian conflict, Conflict Mitigation, FPIC, Indigenous communities, Land rights based on custom.

\section{Introduction}

According to the inventory of the Agrarian Reform Consortium (KPA) in 2017, in Indonesia there are 659 cases of agrarian conflicts with an area of 520,491.87 ha of land and involving as many as 652,738 households. This figure increased $46 \%$ when compared to the previous year (2016) which only as many as 450 cases. In terms of sector-based cases, plantations dominate as much as $32 \%$ (208 cases) with an area of 194,453.27 ha. From that figure, agrarian conflicts of oil palm plantation sector is the largest contributor with 95,565.27 hectares $(49 \%)$. 
Afrizal (2005a) study well illustrates the oppositions committed by affected communities to defend the land they have occupied for a long time, including to demand appropriate compensation and to claim royalties on their customary land used by businesses for the purposes of capital accumulation. The struggles of the local community are often confronted by the power of the state-protected businessmen using repressive means such as beatings, bartering and arrest. If it refers to the latest data, then this pattern has not undergone much change. KPA data show that of 659 cases of agrarian conflicts that occurred during 2017 were dominated by conflicts between local communities and companies (289 cases) and conflicts between local communities and states (140 cases). The use of violent instruments in agrarian conflicts has left 13 people dead, six were shot, 612 people were victims of violence and 369 were criminalized and detained.

Conversion of indigenous forest land to plantations either by the government or by investors often does not involve indigenous peoples or local residents who have settled for generations and are traditionally using forests as their daily sources of livelihood. So the owners of this real right felt their land was confiscated for the benefit of state actors and businessmen. Departing from several studies (Afrizal 2006, 2007, 2013, Colchester and Chao 2012), it is understandable that the main issue in agrarian conflict is the process of land acquisition for investment. There is an element of coercion by state actors and businesspeople to make customary land owners give up their land. Coercion in this case is understood where often local communities do not get complete and clear information about the use of their communal land for the benefit of business capital. The issue of compensation, for example, is not understood by the local community as a transfer of land rights or releases legal ties to the land. Local communities are willing to give up their ulayat land because in perspective they only grant temporary use rights because customary land can not be sold. The issues of legal consequences, and the impacts they will face are often never discussed by the company. This shows that the main issue of land acquisition for investment is land grabbing which does not show recognition and respect for customary rights.

This paper supports the adoption of the principles and criteria of Free, Prior and Informed Consent (FPIC) advocated by activists and international agencies for the mitigation of agrarian conflict to be used as a standard to determine whether or not there is a plunder. The essence of FPIC is the recognition of the rights of affected indigenous communities to self-determination. Based on the review of legislation on environmental permits, land acquisition for public interest and conservation area determination, this paper shows that FPIC is feasible to be applied in Indonesia. This study contributes to the development of knowledge about the handling of agrarian conflicts, particularly on land grabbing literature and how to recognize indigenous peoples' rights to land in plantation investments and forest conservation.

\section{FPIC Fundamentals}

FPIC is a very important communal right to bring about a sustainable development project (Hill et al. 2010: 7). According to Hill et al, the essence of FPIC is that communities can make claims against development projects that have an impact on their livelihoods, lands and territories. For projects that affect the community, effective and comprehensive community participation in planning and implementation negotiations should be guaranteed.

FPIC is a concept that refers to the special rights of local communities that must be respected by all parties. The following describes a brief understanding of each of the terms in 
FPIC. Free, meaning that local communities are free of power, intimidation, manipulation, coercion or pressure by governments and companies. Prior, meaning before the government allocates the land for certain land uses and before approving a particular project, there should be enough time to consider all information and make decisions. Informed, it means you have all the relevant information to make a decision whether to accept or reject the project. The available information should be in a language that you can easily understand. You must have access to independent information sources, not just information from investors / corporations and governments. You should also have access to legal and technical experts, if needed, to assist you in making decisions. Consent, requiring the people involved in the project allow the local community to say accept or reject the project and for each project stages, referring to the decision-making process selected. The right to agree or withhold approval is the most important distinction between the rights of local communities and other project-affected persons.

\section{Sources of FPIC Ideas}

There are a number of regulations that source FPIC ideas, namely: a) UN declaration on the rights of indigenous peoples; b) FAO voluntary standards; c) the Forest Stewardship Council (FSC) voluntary standard. Referring to the UN Declaration on the Rights of Indigenous Communities, adopted at the UN General Assembly on 13 September 2007 in New York, it was stated that indigenous peoples should not be forcibly removed from their lands or territories. No relocation shall take place without free and conscious consent, without coercion from the indigenous peoples concerned, and only after an agreement of fair and satisfactory remedies, and where possible, with the option of returning (art. 10). While in article 11 , it is stated that indigenous peoples have the right to practice and renew their traditions and cultural customs. This includes the right to defend, protect and develop their cultural forms in the past, present and future, such as archaeological and historical sites, artifacts, designs, ceremonies, technology, visual arts and performing arts and literature. Subsequently, states will make restitution through effective mechanisms including restitution, built in conjunction with indigenous peoples, with respect to their cultural, intellectual, religious and spiritual wealth, which have been taken without their free and conscious consent, or violating their laws, traditions and customs. In article 18, it is stated that indigenous peoples have the right to participate in the decision-making process with respect to matters which will have an impact on their rights, through their elected representatives in accordance with their own procedures, as well as to maintain and develop traditional decision-making institutions they have.

The FAO's voluntary publication is intended to contribute to global and national efforts in the fight against hunger and poverty, based on the principles of sustainable development and by recognizing the importance of land for development, by promoting secure tenure rights and equitable access to land, fisheries and forests. In the principles of responsible tenure governance, states should recognize and respect all legitimate tenure holders and their rights. States should take reasonable steps to identify, record and respect legitimate tenure holders and their rights, whether registered or unregistered; does not violate the rights of others; and fulfill obligations related to tenure rights. In addition, the state is also obliged to safeguard the right of legitimate tenure owners from threats and offenses. States shall protect the holders of property rights from arbitrary acts which result in the loss of their tenure or tenure, including 
forced evictions that are inconsistent with state responsibilities under national and international law. On the other hand non-state actors including business enterprises have a responsibility to respect human rights and legitimate tenure rights. Business enterprises should act appropriately to avoid rights violations of human rights and legitimate rights of others. Non-state actors should implement appropriate risk management systems to prevent and deal with adverse impacts on human rights and legitimate tenure rights.

For the realization of responsible forest governance, fisheries and forests, the FAO standard has a number of principles in practice: human dignity, non-discrimination, equity and justice, gender equality, holistic and sustainable approaches, consultation and participation, rule of law, transparency, accountability, and continuous improvement.

The Forest Stewardship Council (FSC) voluntary standard is a guideline for stakeholders in responsible forest governance. The rules that apply to all types and forest areas are aimed at ensuring the realization of environmentally appropriate, economically and socially profitable forest management. There are 10 FSC principles as follows: 1) compliance with applicable laws, regulations and regulations 2) safeguarding and improving the socio-economic aspects of the livelihood of workers, 3) safeguarding and maintaining customary law and customary property rights 4) contributing to the improvement of welfare local communities; 5) efficient management of sustainable forest products and services; 6) maintaining and converting ecosystem services and environmental principles; 7) management planning consistent with objectives and policies; 8) demonstrating progress towards achievement of objectives, impacts of activities, through activities evaluation and monitoring, 9) safeguarding and enhancing high conservation values within the management unit, 10) management activities should be in line with the organization's economy, environmental and social goals and policies.

\section{FPIC As A Structural Agrarian Structural Mitigation Instrument}

FPIC is used as an instrument for mitigating structural agrarian conflicts by Forest Steward Council (FSC) and Roundtable on Sustainable Palm Oil (RSPO). There are two ways in which the two international bodies use FPIC as an instrument of mitigating structural agrarian conflicts. Firstly by establishing and disseminating the rules of recognition and respect for land rights. Secondly by establishing and disseminating conflict management systems.

Rules made by both states that land rights under both state and customary law should be recognized and valued in the production of wood and fruit and palm oil. Both states, if identified on land used for the production of timber and fruit and palm oil, the right to land under both state and customary laws, the consent of the right holder must be made to obtain the land.

- Criteria 2.2 of RSPO P and C: The right to use the land is demonstrated, and is not legitimately contested by local people who can demonstrate that they have legal, customary or user right.

- Criteria 2.3 of RSPO P and C: Use of the land for oil palm does not diminish the legal, customary or user rights of other users without their free, prior and informed consent.

- Criteria 2.2 FSC: Local communities with legal or customary tenure or use rights shall maintain control, to the extent necessary to protect their rights or resources, 
over forest operations unless they delegate control with free and informed consent to other agencies.

- Criteria 3.1 FSC: Indigenous peoples shall control forest management on their lands and territories unless they delegate control with free and informed consent to other agencies.

Then the FSC and RSPO make guidelines on the implementation of FPIC in the production of wood and fruit and palm oil. With assistance from Forest Peoples Program the RSPO developed a FPIC Guide for Companies In 2007-2008. A revised version of the guideline has been issued in 2015. The FSC and RSPO FPIC implementation guidelines outline how a timber producer company and palm oil plantation company should implement FPIC in the acquisition process of community's land.

Both have established the dispute resolution system to resolve disputes. The system consists of procedures of filing complaints, complaints handling procedures by the FSC, the appeals procedure of the FSC decision and the norms governing the implementation of complaints filing, complaints handling, and decisions by the FSC. In doing so, both the FSC and the RSPO have the authority to act as the agency for the settlement of forestry conflict and oil palm plantations. This does not mean that both replace the role of government and governmental justice, but alternatives for both communities to seek justice for the violation of their rights to natural resources by the production of fruit and palm oil and timber.

\section{Development of FPIC Receipts in Indonesia}

Since the early 2000s, social NGOs have encouraged the implementation of FPIC in palm oil production. Their advocacy has been responded by the Indonesian government by incorporating FPIC into licensing regulations to investors and land acquisition by investors. Tables 1 and 2 below show FPIC in Indonesian law.

Table 1. Legislation That Contains FPIC

\begin{tabular}{|c|c|c|}
\hline No & Law & Norrm \\
\hline 1 & $\begin{array}{l}\text { Law of the Republic of } \\
\text { Indonesia Number } 2 \text { of } \\
2012\end{array}$ & 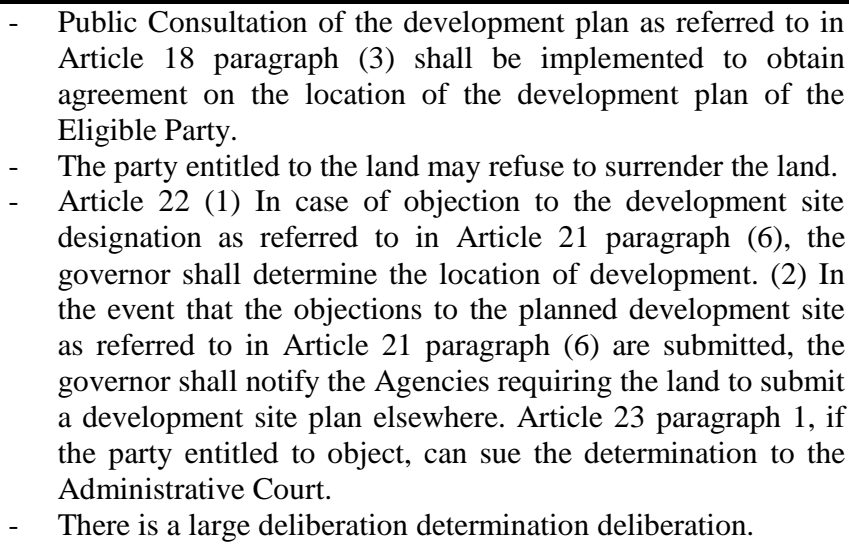 \\
\hline 2 & $\begin{array}{l}\text { Regulation of the } \\
\text { President of the Republic } \\
\text { of Indonesia Number } 71\end{array}$ & $\begin{array}{l}\text { - Article 32: Content of public consultations: } \\
\text { - a. the purpose and objective of the development plan for the } \\
\text { public interest; b. stages and time of process of Land }\end{array}$ \\
\hline
\end{tabular}




\author{
Year 2012 and \\ Regulation of the \\ President of the Republic \\ of Indonesia Number 30 \\ Year 2015 revision to No. \\ $71 / 2010$
}

Decree of the Minister of Agrarian Affairs / Head of National Land Agency Number 21 of 1994 Concerning Procedure of Land Acquisition for Companies in the Framework of Investment

4. Regulation of the Minister of Agrarian Affairs / Head of BPN No. 5 year 2015 about Location permission

5 Minister of Agriculture of the Republic of Indonesia Regulation no. 11 of 2015 on ISPO Principles and Criteria

$6 \quad$ Plantation Law

$7 \quad$ 1. Government Regulation No. 27 of 2012 on Environmental Permits
Procurement; $c$. the role of the Valuer in determining the value of Indemnification; d. incentives to be given to rights holders; e. Objects that are subject to Replace Losses; f. Indemnification forms; and g. rights and obligations of the Eligible Person.

- In a Public Consultation a dialogue process is conducted between the Preparatory Team and the Eligible Party as referred to in Article 29 and affected communities as referred to in Article 30.

- Public Consultation is a process of dialogical communication or consensus among stakeholders in order to reach agreement and agreement in Land Procurement planning for development for public interest.

- Article 2 paragraph (2) Acquisition of land is exercised directly between the company and the owner or holder of land rights on an agreement basis.

- (2) The acquisition of land through the transfer of rights shall be carried out if the land concerned has been owned by a right of land of the same kind as the land rights done by the company in running its business.

- Article 13 (1) Delivery or disposal of land rights for the purpose of the company in the framework of execution of the Location Permit shall be done by the holder of the right or proxy by the statement of delivery or disposal of land rights made before the Head of the local Land Office by using the form in Appendix V of this Decision example.

- Attachment mentions "LETTER OF SUBMISSION / DISCLAIMER OF THE RIGHT TO LAND" .... hereby declare to surrender the land of possession / release *) ... and then we do not mind if it is over the land is requested with a right to land by

- The letter of release of the land is known by the head of the National Defense Agency of the Regency.

- Permit location permits to the company to acquire land, not land rights. The right to land is granted to the owner of the location permit after completion of land acquisition.

- Article 12. Location permit holders acquire land based on agreements from holders of land rights.

- Land acquisition derived from customary / customary rights shall first be consulted with the customary law community of customary rights holders and the rights holders of the land concerned in the form of land delivery agreements and the remuneration known to the governor / regent / mayor in accordance with the authority.

- In case the Land needed for the Plantation Business is customary land of customary law community, the plantation business actor shall conduct consultation with the Customary Law Community of the ulayat right holders to obtain approval on the delivery of land and the remuneration.

- In the preparation of AMDAL documents, the proponent involves the community and one of them is by public consultation.

- Article 2 The implementation of community involvement in 


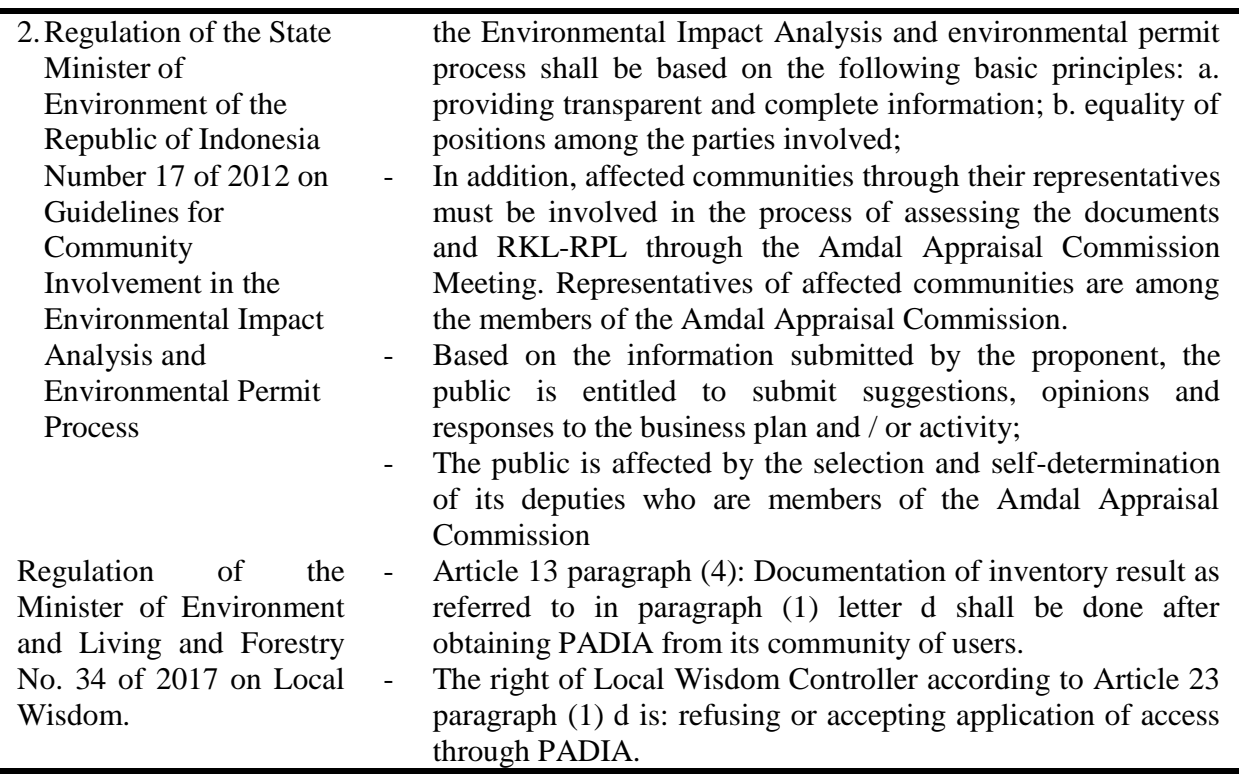

As seen in the table above, the use of the word deliberation, public consultation with dialogical communication, land delivery agreement, and the existence of the phrase of surrendering the land rights based on the contents of the land release letter further we do not object if the land is requested with a right to land by ....... are the normative foundations of FPIC in the process of disposal of land rights, including customary rights.

Table 2. Laws That Acknowledge and Appreciate Land Rights Based on Adat

\begin{tabular}{|c|c|c|}
\hline No & Law & Norm \\
\hline 1 & The Law of 1945 & $\begin{array}{l}\text { Article 18B paragraph (2): The State recognizes and respects the } \\
\text { unity of indigenous and tribal peoples ... }\end{array}$ \\
\hline 2 & Basic Agrarian Law & $\begin{array}{l}\text { Article } 3: \ldots \text { the exercise of customary rights ... of indigenous } \\
\text { and tribal peoples ... shall be such ... (elucidation of article: this } \\
\text { is the recognition of customary rights and the need to hear the } \\
\text { opinion of ulayat rights holders in the government's effort to } \\
\text { grant the right to land. }\end{array}$ \\
\hline 3 & $\begin{array}{l}\text { Minister of Agriculture of } \\
\text { the Republic of Indonesia } \\
\text { Regulation no. } 11 \text { of } 2015 \\
\text { on ISPO Principles and } \\
\text { Criteria }\end{array}$ & $\begin{array}{l}\text { The land of oil palm plantations can come from Indigenous / } \\
\text { Ulayat lands from Indigenous Peoples. }\end{array}$ \\
\hline 4 & MK 35 & Customary forest is not a state forest. \\
\hline
\end{tabular}

As a result of the RSPO campaign and the pressure of human rights NGOs, large oil palm plantation companies (including Wilmar International, APRIL Group, Golden Agri, PT SMART TBK, Cargill, Musim Mas) have declared their commitment to implement FPIC in land acquisition and dispute resolution processes . 


\section{Conclusion}

FPIC is an international standard that is recommended to be applied to address the weaknesses of national law in respect of land rights based on customs. The essence of FPIC is the recognition of the rights of affected indigenous communities to self-determination. Based on a review of legislation on environmental permits and land acquisition for public and private interests and the commitment of large oil palm plantation companies, FPIC is feasible to be implemented in Indonesia. To examine the benefits of FPIC as a regulation of structural agrarian conflicts in Indonesia, research on the implementation of FPIC is required in the provision of environmental permits, land acquisition and conflict resolution of plantation, mining and environment industries.

\section{References}

[1] Elsam. Deklarasi Perserikatan Bangsa- Bangsa tentang Hak-hak Masyarakat Adat.

[2] Afrizal. 2005. The Nagari Community, Business and the State: The Origin and the Process of Contemporary Agrarian Protests in West Sumatra, Indonesia, Forest Peoples Programme and Sawit Watch, Bogor.

[3] Afrizal. 2010. 'Large scale palm oil plantation development, recognition of local people's customary rights and agrarian conflicts in Indonesia after the fall of President Soehar to: a lesson learned from provinces of West Sumatra and Riau', CIAS Discussion Paper Series No. 15, Center for Integrated Area Studies (CIAS), Kyoto:97-126.

[4] Afrizal. 2013)'Oil palm plantations, customary rights, and local protest', in A. Lucas and C.Warren (eds) Land for the People: The State and Agrarian Conflict in Indonesia, Ohio University Press, Athens, OH:149-82.

[5] Afrizal. 2015. 'Third-party intervention in terminating oil palm plantation conflict in Indonesia: a structural analysis', SOJOURN: Journal of Social Issues in Southeast Asia, 30(1):141-72.

[6] Afrizal and Anderson Patrick. 2016. "Industrial Plantation and Community Rights: Conflicts and Solutions", in John McCarthy and Kathryn Robinson, ISEAS, Singapore.

[7] Afrizal, Arifin Zainal, Setyaka Virtous, Zuldesni. 2016. "Dampak Perubahan Sosial-politik Makro terhadap Proses Akuisisi Tanah untuk Perkebunan Kelapa Sawit: Studi Pengaruh Konteks Sosial-Politik terhadap Penerapan Prinsip dan Kritiria FPIC RSPO. Laporan Penelitian yang tidak Dipublikasikan.

[8] Colchester, M. And S. Chao (eds) (2013) Conflictor Consent? The Oil Palm Sector at a Crossroads, Forest Peoples Programme, Sawit Watch and TUK Indonesia, Moreton-in-Marsh, Bogorand Jakarta.

[9] Hill, Christina, Serena Lillywhite and Michael Simon. 2010. Guide to Free Prior and Informed Consent. Victoria: Oxfam Australia.

[10] April, http://www.aprilasia.com/en/sustainability/sustainability-policy, diakses tanggal $30 \mathrm{Mei}$ 2016.

[11] BPS (Badan Pusat Statistik). 2013. Statistical Year book of Indonesia, Statistics Indonesia (BPS), Jakarta.

[12] Cariño Joji. 2015. Indigenous Peoples' Right to Free, Prior, Informed Consent: Reflections On Concepts And Practice. http://arizonajournal.org/wp-content/uploads/2015/11/CarinoFormatted.pdf, accessed in May 2016.

[13] Colchester, M., N. Jiwan, A. Martua Sirait, A.Y. Firdaus, A. Surambo and H. Pane. 2006. Promised Land: Palm Oil and Land Acquisition in Indonesia: Implications for Local Communities and Indigenous Peoples, Forest Peoples Programme, PerkumpulanSawit Watch, HuMA and the World Agroforestry Centre,Moreton-in-Marsh and Bogor. 
[14] Dahrendorf Ralf, 1959. Class and Class Conflict in Industrial Society. Stanford University Press. California.

[15] Dewan Kehutanan Nasional and UN-REDD Programme Indonesia. 2011. "Policy recommendations: the instrument free, prior and informed consent (FPIC) of indigenous peoples and the local community that will be affected in the activities of REDD + in Indonesia", National Forestry Council) and UN-REDD Programme Indonesia, Jakarta.

[16] FAO-UN. 2012. Voluntary Guidelines on the Responsible Governance of Tenure of Land, Fisheries and Forests in the Context of National Food Security. Rome : Food And Agriculture Organization of the United Nations.

[17] RSPO (Roundtable on Sustainable Palm Oil) (2013) 'Principles and criteria for the production of sustainable palm oil 2013', RSPO, April.

[18] https://ic.fsc.org/en/what-is-fsc-certification/principles-criteria/fscs-10-principles

[19] Lucas,A. 1997. 'Land disputes, the bureaucracy, and local resistance in Indonesia', dalam J.Schillerand B.Martin-Schiller (eds) Imagining Indonesia: Cultural Politics and Political Culture, Ohio University Press, Athens, OH:229-60. 